\title{
ZJAWISKO GŁOSÓW NIEWAŻNYCH W WYBORACH DO SEJMIKÓW WOJEWÓDZW W 2014 ROKU NA PODSTAWIE BADAŃ KART WYBORCZYCH Z ARCHIWUM PAŃSTWOWEGO W KIELCACH
}

\begin{abstract}
The phenomenon of invalid votes in elections to regional assemblies in 2014 on the basis of voting paper studies at the National Archive in Kielce
\end{abstract}

The aim of the article is the analysis of invalid votes in elections to regional assemblies in 2014, done on the basis of the studies of voting papers at the National Archives in Kielce. The studies were undertaken within the research project called 'Your voice, your choice', conducted by the Stefan Batory Foundation in collaboration with the National Electoral Office, National Electoral Commission and the Head Office of National Archives. The analysis encompassed 29 electoral districts that included: 10 electoral districts from the Lesser-Poland Voivodeship, 7 from the Lublin Voivodeship and 6 from the świetokrzyskie Voivodeship. Apart from indicating the reason for the occurrence of invalid votes in elections to regional assemblies, a detailed classification of the abovementioned votes was provided, that included the division into votes with an extra ' $x$ ' signs, null votes, votes with signs different than ' $x$ ', votes with multiple ' $x$ ' signs and strikethroughs, protest votes and the so-called distinct votes. On this basis a characteristic of territorial variation of these votes was provided.

Keywords: invalid votes, local government elections, provincial council, polling of ballot papers

\section{Streszczenie}

Celem artykułu jest analiza zjawiska głosów nieważnych w wyborach do sejmików województw w 2014 roku, przeprowadzona na podstawie badania kart wyborczych w Archiwum Państwowym w Kielcach. Badania te podjęto w ramach projektu badawczego pt. „Masz 
Głos, Masz Wybór", zrealizowanego przez Fundację im. Stefana Batorego we współpracy z Krajowym Biurem Wyborczym, Państwową Komisją Wyborczą oraz Naczelną Dyrekcją Archiwów Państwowych. Analizą objęto dwadzieścia dziewięć obwodów wyborczych, na które złożyły się: dziesięć obwodów wyborczych z województwa małopolskiego, siedem z województwa lubelskiego, sześć z województwa podkarpackiego i sześć z województwa świętokrzyskiego. Oprócz wskazania przyczyn występowania głosów nieważnych w wyborach do sejmików województw dokonano szczegółowej klasyfikacji tychże głosów z ich podziałem na głosy z nadmiarowymi znakami „x”, głosy puste, głosy stanowiące inny znak niż „x”, głosy $\mathrm{z}$ wieloma znakami „X” i przekreśleniami, głosy protestu i tak zwane głosy różne. Na tej podstawie dokonano charakterystyki zróżnicowania terytorialnego tych głosów.

Słowa kluczowe: głosy nieważne, wybory samorządowe, sejmik wojewódzki, badanie kart wyborczych

\section{Wprowadzenie}

Przeprowadzone w listopadzie 2014 roku wybory samorządowe wzbudziły wiele kontrowersji za sprawą przynajmniej kilku czynników wzajemnie ze sobą skorelowanych. Po pierwsze, zawiódł system elektronicznego liczenia głosów opracowany przez firmę Nabino, który znacznie wydłużył okres oczekiwania na ogłoszenie oficjalnych wyników przez Państwową Komisję Wyborczą (dalej: PKW). Po drugie, pojawiła się dość istotna rozbieżność między wynikami sondażu exit poll przeprowadzonego przez Ipsos a ostatecznymi wynikami wyborów, przez co spora liczba komentatorów sceny politycznej oraz liderów partyjnych podnosiła argument o „sfałszowaniu” i ,zniekształceniu” wyborów lub też o „,nieprawidłowościach”, „,nadużyciach” i „nierzetelności” przy liczeniu samych głosów [Michalak, 2016b: 223-226]. Owa rozbieżność dotyczyła w sposób szczególny Polskiego Stronnictwa Ludowego (PSL), które zanotowało znacznie wyższe poparcie społeczne w wyborach do sejmików województw, aniżeli przewidywano to w badaniach sondażowych. Po trzecie, w wyborach samorządowych z 2014 roku zwrócono szczególną uwagę na stosunkowo wysoki odsetek głosów nieważnych, który wyniósł aż dwa i pół miliona, czyli prawie $18 \%$ wszystkich ważnie oddanych głosów. Jak zauważył trafnie Adam Gendźwiłł, „część komentatorów powiązała ów przyrost ze zmianą wyglądu kart do głosowania, tzn. ich zbroszurowaniem" [Gendźwiłł, 2015b: 54], co w konsekwencji mogło przyczynić się do wprowadzenia w błąd obywateli udających się do urn wyborczych. Źródłem dodatkowej konsternacji pojawiającej się w związku z analizą wyniku wyborów samorządowych z 2014 roku był brak w protokołach PKW informacji na temat przyczyn głosów nieważnych i ich szczegółowej klasyfikacji. Sytuacja ta wynikała wprost z obowiązującego od 5 stycznia 2011 roku Kodeksu wyborczego (Dz.U. 2019, poz. 684 tekst jedn. ze zm., dalej: Kodeks wyborczy), w którym zniesiono dotychczasowy obowiązek podawania w protokołach obwodowych komisji wyborczych szczegółowych informacji na temat przyczyn oddania głosów nieważnych, przez co nie było możliwości porównania tych proporcji z wynikami wyborów samorządowych z lat wcześniejszych. 
Wskazane wyżej imponderabilia przyczyniły się do zainicjowania w 2015 roku ogólnopolskiego projektu badawczego pt. „Masz Głos, Masz Wybór” zrealizowanego przez Fundację im. Stefana Batorego we współpracy z Krajowym Biurem Wyborczym, Państwową Komisją Wyborczą oraz Naczelną Dyrekcją Archiwów Państwowych. Jego pomysłodawcami było trzynastu ekspertów - politologów, socjologów oraz prawników specjalizujących się w problematyce wyborczej, reprezentujących akademickie ośrodki naukowe z Warszawy, Krakowa, Torunia i Wrocławia. Wśród najważniejszych założeń, które legły u podstaw tego projektu, było uzyskanie odpowiedzi na następujące pytania: jakie były przyczyny wysokiego odsetka głosów nieważnych oddanych podczas wyborów samorządowych w 2014 roku? Jaki wpływ na ostateczny wynik wyborów miała zastosowana forma kart do głosowania w postaci książeczki? Jakie działania należałoby podjąć w przyszłości, by uniknąć podobnych sytuacji?

Poniższe analizy stanowiły jedynie fragmentaryczny wycinek ogólnopolskiego badania kart wyborczych, które autor wraz z gronem ekspertów z Instytutu Nauk o Polityce Uniwersytetu Rzeszowskiego przeprowadził w Archiwum Państwowych w Kielcach w dniach 5-9 października 2015 roku. Badaniem objęto łącznie dwadzieścia dziewięć obwodów wyborczych z województw: lubelskiego, małopolskiego, podkarpackiego i świętokrzyskiego. Należy podkreślić, iż z punktu widzenia metodologicznego nie były one reprezentatywne dla wspomnianych województw.

\section{Głosy nieważne}

Dotychczasowe zasady przeprowadzania wyborów w Polsce do końca 2010 roku regulowane były różnorodnymi aktami, począwszy od Konstytucji Rzeczypospolitej Polskiej z dnia 2 kwietnia 1997 roku (Dz.U. 1997, nr 78, poz. 483 ze zm.), przez liczne ustawy i rozporządzenia. Były one uchwalane w różnym czasie, podlegały częstym nowelizacjom, co w zasadzie ograniczało ich czytelność oraz powodowało niespójność całego systemu wyborczego (ustawa z dnia 27 września 1990 roku o wyborze Prezydenta Rzeczypospolitej Polskiej, Dz.U. 2010, nr 72, poz. 467 ze zm.; ustawa z dnia 16 lipca 1998 roku Ordynacja wyborcza do rad gmin, rad powiatów i sejmików województw, Dz.U. 2010, nr 176, poz. 1190 ze zm.; ustawa z dnia 12 kwietnia 2001 roku Ordynacja wyborcza do Sejmu Rzeczypospolitej Polskiej i do Senatu Rzeczypospolitej Polskiej, Dz.U. 2007, nr 190, poz. 1360 tekst jedn. ze zm.; ustawa z dnia 20 czerwca 2002 roku o bezpośrednim wyborze wójta, burmistrza i prezydenta miasta, Dz.U. 2010, nr 176, poz. 1191; ustawa z dnia 23 stycznia 2004 roku Ordynacja wyborcza do Parlamentu Europejskiego, Dz.U. 2004, nr 25, poz. 219 ze zm.). Warto podkreślić za Andrzejem Stelmachem, iż po 1989 roku mieliśmy do czynienia w zasadzie z trzema okresami ewolucji ordynacji wyborczych. Były to: 1) okres poszukiwań (19891991); 2) okres stabilizacji naprzemiennej (1993-1997-2001) i 3) okres koncentracji (2005-2007) [Stelmach, 2010: 9 i n.]. Dopiero wraz z uchwaleniem Kodeksu wyborczego z 2011 roku kompleksowo uregulowano sposób i warunki 
przeprowadzenia wyborów dla każdej elekcji z osobna. Jak podkreśla się w literaturze przedmiotu, przyjęcie jednolitego aktu normatywnego nie stanowiło o pogłębieniu refleksji czy też o przeprowadzeniu rzetelnej analizy obowiązujących regulacji, lecz jedynie doprowadziło do skompilowania dotychczasowych rozwiązań z poprzednich regulacji $\mathrm{w}$ jednym dokumencie $\mathrm{z}$ jednoczesnym uzupełnieniem i zmodyfikowaniem obowiązujących procedur [Skotnicki, 2011: 33; Sieklucki, 2015: 83-84; Śleszyński, 2015: 65-68].

Nie aspirując $w$ niniejszych szkicach do analizy samorządowego systemu wyborczego, skoncentruję się na zjawisku głosów nieważnych oraz głównych przyczynach ich występowania. Skala tego procesu jest wysoce zróżnicowana oraz zależy od rodzaju elekcji wyborczej. Jak trafnie zauważył Arkadiusz Ptak, po wyborach samorządowych w 2010 roku zjawisko głosów nieważnych zostało wykorzystane jako element walki politycznej [Ptak, 2012: 58].

Obowiązująca do 2010 roku ordynacja wyborcza w klarowny sposób precyzowała, w jakiej sytuacji mieliśmy do czynienia z głosem nieważnym. W wyborach do rady gmin, w ramach których na ogół stosowano formułę większościową lub quasi-proporcjonalną, głos był uznawany za nieważny, jeśli na karcie do głosowania postawiono znak „x" obok nazwisk większej liczby kandydatów niż liczba radnych wybieranych w okręgu lub też gdy nie postawiono znaku „x” obok nazwiska żadnego kandydata. W pozostałych wyborach do organów samorządu terytorialnego, w ramach których wybory przeprowadzano, opierając się na formule proporcjonalnej, głos był uznawany za nieważny, jeśli na karcie do głosowania postawiono znak „, ” obok nazwiska dwóch lub większej liczby kandydatów $\mathrm{z}$ różnych list wyborczych lub nie postawiono znaku „,x” obok nazwiska żadnego kandydata $\mathrm{z}$ którejkolwiek listy wyborczej. Dodatkowo głos był nieważny, jeśli na karcie do głosowania postawiono znak „„” przy nazwisku kandydata, który został skreślony z listy kandydatów już po wydrukowaniu list wyborczych [Michalak, 2016a: 57-60].

Jak już wspomniano, w przyjętej w 2011 roku ustawie Kodeks wyborczy nie sprecyzowano tego, czym jest głos nieważny. Dopiero wskutek wydarzeń związanych z wyborami samorządowymi w 2014 roku dokonano nowelizacji Kodeksu wyborczego. Zasadniczą konkluzją zawartą w Opinii do ustawy o zmianie ustawy Kodeks wyborczy (druk nr 901) było „wskazywanie w protokołach komisji wyborczych przyczyn nieważności oddanych głosów" [Kancelaria Sejmu, 2015: 2]. W związku z tym opowiedziano się za koniecznością wprowadzenia przepisów zobowiązujących komisje wyborcze do wymienienia w protokołach głosowania przy liczbie głosów nieważnych przyczyn ich nieważności. Już w znowelizowanej ustawie, w rozdziale 5 pt. Sposób głosowania $i$ warunki ważności głosu, stwierdzono, że głos uznaje się za nieważny, jeśli na karcie do głosowania postawiono znaki „X” w kratce $\mathrm{z}$ lewej strony obok nazwiska więcej niż jednego kandydata z różnych list wyborczych lub też gdy nie postawiono znaku „,”” obok nazwiska żadnego kandydata. Ponadto głos uznano za nieważny, jeśli na karcie do głosowania postawiono znak , X” w kratce z lewej strony obok nazwiska kandydata, którego rejestracja została unieważniona. Wytyczne te powtórzono w uchwale Państwowej Komisji Wyborczej z dnia 29 września 2014 roku w sprawie wytycznych 
dla obwodowych komisji wyborczych dotyczących zadań i trybu przygotowania oraz przeprowadzenia głosowania w wyborach organów jednostek samorządu terytorialnego, zarządzonych na dzień 16 listopada 2014 roku, M.P. 2014, poz. 934.

\section{Głosy nieważne w świetle badania kart wyborczych w Archiwum Państwowym w Kielcach}

Koncentrując zasadniczą uwagę na wynikach przeprowadzonych badań kart wyborczych do sejmików województw, należy stwierdzić, iż w dwudziestu dziewięciu analizowanych obwodach wyborczych oddano łącznie ponad 2000 głosów nieważnych. Według protokołów obwodowych komisji wyborczych było ich dokładnie 2336, natomiast według badania przeprowadzonego w ramach projektu ich liczba była znacznie mniejsza: 2188 głosów. Wskazana proporcja wynosząca w sumie aż 148 głosów różniła się w zależności od województwa. W województwie lubelskim protokoły obwodowych komisji wyborczych wykazały 521 głosów nieważnych, natomiast według badania było ich 489 . W województwie małopolskim wykazano 900 głosów nieważnych, podczas gdy według badania było ich 871. Z kolei w województwie podkarpackim zgodnie $\mathrm{z}$ danymi obwodowych komisji wyborczych padło 342 głosów nieważnych, podczas gdy badania wykazały, że było ich 337. Liczba głosów nieważnych w województwie świętokrzyskim według protokołów obwodowych komisji wyborczych wynosiła 573, natomiast zgodnie z obliczeniami badaczy była ona mniejsza o 82 głosy i wyniosła ostatecznie 491. Dane te szczegółowo przedstawiono w tabeli 1.

Tabela 1

Liczba głosów nieważnych z podziałem na badane województwa

\begin{tabular}{|l|c|c|c|}
\hline Województwo & $\begin{array}{c}\text { Liczba zbadanych } \\
\text { obwodów wyborczych }\end{array}$ & $\begin{array}{c}\text { Liczba glosów nieważ- } \\
\text { nych wedlug badania }\end{array}$ & $\begin{array}{c}\text { Liczba glosów nieważ- } \\
\text { nych według } \\
\text { protokołu OKW }\end{array}$ \\
\hline Lubelskie & 7 & 489 & 521 \\
\hline Małopolskie & 10 & 871 & 900 \\
\hline Podkarpackie & 6 & 337 & 342 \\
\hline Świętokrzyskie & 6 & 491 & 573 \\
\hline Razem & 29 & 2188 & 2336 \\
\hline
\end{tabular}

Źródło: opracowanie własne na podstawie analizy materiału z obwodowych komisji wyborczych przekazanych do Archiwum Państwowego w Kielcach.

Najbardziej interesującym problemem badawczym było jednak określenie przyczyn tak wysokiej liczby głosów nieważnych oddanych w analizowanych obwodach wyborczych. Oczywiście, stwierdzenie powodu nieważności głosu nie dostarczyło nam wiarygodnych informacji dotyczących samej intencji wyborcy, który taki 
głos oddał. Na ogół przyjmowano uproszczenie, zgodnie z którym oddanie głosu pustego traktowane było jako zamierzone wstrzymanie się od oddania głosu. Obywatele, którzy nie posiadali sprecyzowanych preferencji lub sympatii politycznych, w akcie głosowania oddawali zatem puste karty lub stawiali na nich nadmiarową liczbę krzyżyków. Działania takie mogły być celowe, wynikać z pomyłki wyborcy lub też niewłaściwego poinformowania głosującego na temat prawidłowych technik oddania głosu ważnego. Na podstawie powyższego przykładu trudno było w sposób jednoznaczny wskazać, jakie były docelowe preferencje głosującego oraz jakie przeszkody stanęły na drodze do ich skutecznego i prawidłowego wyrażenia. $\mathrm{W}$ dotychczasowej praktyce związanej z udziałem obywateli w akcie głosowania pojawiały się liczne przypadki oddania w sposób intencjonalny głosu nieważnego przez umieszczenie na karcie do głosowania różnego rodzaju dopisków czy komentarzy. Innymi przykładami takich zachowań były między innymi: niezaznaczenie nazwiska któregokolwiek z kandydatów, przekreślenie nazwisk bądź też całej listy kandydatów [Gendźwiłł i in., 2016: 63-64].

Jeśli chodzi o techniki głosowania w Polsce, warto podkreślić, iż mamy do czynienia ze stosunkowo restrykcyjnym sposobem oddawania głosu polegającym na wskazaniu przez wyborców kandydata oraz postawieniu znaku „X” w kratce umieszczonej obok jego nazwiska. W praktyce jednak zauważalna była dowolna twórczość głosujących realizowana przez stawianie znaków innych niż „x”. Mimo iż powyższa intencja była czytelna, to w kontekście czysto urzędowym traktowana była jako głos nieważny.

W ramach końcowego raportu uwzględniającego reprezentatywną probę obwodów głosowania dokonano szczegółowego sklasyfikowania głosów nieważnych. W ten sposób wyróżniono: głosy z wieloma krzyżykami (wiele znaków „x” umieszczonych wyłącznie w kratkach - głosowanie na wielu kandydatów); głosy puste (wyborca nie zdecydował się na wstawienie znaku ,x" lub jakiegokolwiek innego znaku przy nazwisku któregokolwiek z kandydatów); głosy zawierające inny znak (wstawianie innych, tak zwanych niedozwolonych znaków - w tym rozumieniu innych niż „,x”); głosy $\mathrm{z}$ wieloma znakami w kratkach lub przekreśleniami (umieszczenie na karcie do głosowania wielu znaków „,x” lub innych znaków w kratkach lub poza kratkami, stanowiących często przejaw twórczości głosującego, komentarze, „,bazgroły”); głosy różne (więcej niż jeden powód nieważności głosu, na przykład wiele znaków innych niż „x" wstawionych w kratkach lub poza kratkami) oraz tak zwane głosy protestu (na przykład przekreślenie nazwiska, nazwisk lub całej listy kandydatów; na głos protestu wskazywały również dopiski i rysunki) [Gendźwiłł i in., 2016: 64].

Z przeprowadzonego badania kart wyborczych w Archiwum Państwowych w Kielcach wynika, że największy odsetek głosów nieważnych dotyczył umieszczenia na karcie wyborczej przez głosujących wielu znaków „x” oraz głosów pustych, a w dalszej kolejności były to głosy oznaczone jako inny znak oraz głosy z wieloma znakami w kratce i poza kratką lub przekreśleniami, głosy różne i głosy protestu. Wskazując na terytorialne zróżnicowanie oddanych głosów nieważnych (tabela 2), należy zauważyć, iż odsetek ten był najwyższy w województwie małopolskim, w którym oddano: 472 głosy puste, 367 głosów $\mathrm{z}$ wieloma znakami „,x”, 18 głosów zawierających inny znak niż „x”, 7 głosów z wieloma znakami „,x” i przekreśleniami, 6 głosów 
Tabela 2

Powody nieważności głosów w wyborach do sejmików województw w 2014 roku w świetle badania kart wyborczych w Archiwum Państwowym w Kielcach

\begin{tabular}{|l|c|c|c|c|c|c|}
\hline $\begin{array}{c}\text { Badane } \\
\text { województwo }\end{array}$ & $\begin{array}{c}\text { Wiele } \\
\text { krzyżyków }\end{array}$ & $\begin{array}{c}\text { Glos } \\
\text { pusty }\end{array}$ & $\begin{array}{c}\text { Inny } \\
\text { znak }\end{array}$ & Różne & $\begin{array}{c}\text { Glos } \\
\text { z wieloma } \\
\text { znakami } \\
\text { w kratkach } \\
\text { lub prze- } \\
\text { kreśleniami }\end{array}$ & $\begin{array}{c}\text { Glos } \\
\text { protestu }\end{array}$ \\
\hline Lubelskie & 231 & 236 & 11 & 7 & 4 & - \\
\hline Małopolskie & 367 & 472 & 18 & 2 & 7 & 5 \\
\hline Podkarpackie & 148 & 171 & 5 & 4 & 9 & - \\
\hline Świętokrzyskie & 324 & 145 & 13 & - & 3 & 6 \\
\hline Razem & 1070 & 1024 & 47 & 13 & 23 & 11 \\
\hline
\end{tabular}

Źródło: opracowanie własne na podstawie analizy materiału z obwodowych komisji wyborczych przekazanych do Archiwum Państwowego w Kielcach.

protestu i 2 głosy różne. Drugie miejsce pod względem liczby głosów nieważnych zajęło województwo świętokrzyskie, w którym oddano: 145 głosów pustych i ponad dwa razy więcej głosów z wieloma znakami „,x” (324), 13 głosów z innymi znakami, 6 głosów protestu i 3 głosy z wieloma znakami w kratce i poza kratką lub przekreśleniami. $Z$ kolei w województwie lubelskim widoczna była niewielka różnica pomiędzy liczbą głosów z wieloma znakami „x” a liczbą głosów pustych. Odsetek ten wyniósł 231 do 236 głosów, przy czym warto podkreślić, iż w analizowanych obwodach wyborczych z tego obszaru nie padł żaden głos protestu. Pojawiło się za to: 11 głosów zaklasyfikowanych jako inny znak, 7 jako głosy różne i 4 oznaczone jako głosy z wieloma znakami w kratce lub poza nią i przekreśleniami. Na Podkarpaciu wykazano natomiast: 148 głosów $\mathrm{z}$ wieloma znakami „,x”, 171 głosów pustych, 9 oznaczonych jako głosy z wieloma znakami w kratce i poza kratką lub przekreśleniami, 6 zawierających inny znak niż „x” oraz 4 głosy różne. W badaniu kart z tego województwa nie zaklasyfikowano głosów protestu.

\section{Podsumowanie}

Wnioski, jakie wynikają z przeprowadzonych badań z dwudziestu dziewięciu obwodowych komisji wyborczych, wpisują się w tezę przedstawioną przez grono ekspertów z Fundacji im. Stefana Batorego, zgodnie z którą jedną z dwóch najważniejszych przyczyn nieważności głosów w wyborach do sejmików województw z 2014 roku było postawienie przez głosujących nadmiarowych znaków „x” umieszczonych w kratkach przy nazwiskach kandydatów z różnych list [Gendźwiłł, 2015a: 36-37; Gendźwiłł i in., 2016: 85 i n.]. Liczba tych głosów wyniosła aż 1070. Drugą zasadniczą przyczyną nieważności głosów było, identycznie 
zresztą jak w elekcjach z lat 2006 i 2010, oddanie głosu pustego, bez wskazania preferencji wyborczej. W analizowanych województwach liczba głosów pustych wyniosła 1024 . W przypadku pozostałych przyczyn nieważności głosów, które zaklasyfikowano jako znak inny niż „x”, głosy z wieloma znakami w kratkach lub przekreśleniami, głosy różne oraz głosy protestu tylko w sposób znikomy i nieznaczny miały wpływ na zwiększenie ogólnej liczby głosów nieważnych.

Koncentrując się na dwóch najważniejszych przesłankach głosów nieważnych z wyborów do sejmików województw z 2014 roku, można dojść do kilku ważnych konkluzji. Po pierwsze, obywatele biorący udział w głosowaniu stawiali najczęściej znak „x" na każdej liście wyborczej oraz - jak pokazały to przeprowadzone badania - przynajmniej po kilka znaków „x” na tej samej liście do głosowania. Mogło to być wynikiem niedoinformowania obywateli na temat technik głosowania lub mylących instrukcji wyborczych opracowanych przez Państwową Komisję Wyborczą albo też świadomym i intencjonalnym działaniem głosującego, który przez takie zachowanie dawał do zrozumienia, iż uczestniczył w wyborach z zamiarem oddania głosu nieważnego.

Po drugie, w przypadku tak dużej liczby głosów pustych trudno było dokonać syntetycznej i merytorycznej analizy, gdyż na podstawie tylko samych kart do głosowania otrzymaliśmy materiał obarczony dużą liczbą niewiadomych. Na tej postawie można jedynie formułować pewne hipotezy odnoszące się chociażby do tradycji głosowań. Obywatele oddający swój głos do urny wyborczej wyrażali zainteresowanie wyłącznie organami wybieranymi bezpośrednio w ich miejscu zamieszkania. Na ogół byli to: prezydent, wójt i burmistrz, nieco rzadziej już rada miasta, rada gminy czy rada powiatu. Sejmik wojewódzki w tym układzie odniesienia zajmował ostatnie miejsce. Prawdopodobnie wynikało to $\mathrm{z}$ braku zainteresowania i samego niezrozumienia przez obywateli roli i zadań tego organu oraz traktowania go jako instytucji odległej oraz o niejasnych celach.

Po trzecie, oddanie głosów nieważnych stanowić mogło również o dezaprobacie obywateli wobec bieżącej polityki, samych polityków i ich partii politycznych; mogło też być wyrazem rozczarowania sytuacją społeczną, polityczną i gospodarczą kraju bądź też wynikać z niezadowolenia z sytuacji panującej w miejscowości zamieszkania. Niezależnie jednak od wymienionych tu przyczyn głosów nieważnych trudno było podjąć dywagacje odnoszące się do zamierzonych i niezamierzonych zachowań wyborczych obywateli, które zależnie od nastroju, przekonań politycznych oraz wielu innych czynników ostatecznie wpłynęły na ich udział w akcie głosowania.

\section{Bibliografia}

Gendźwiłł A. (2015a), Brakujące i nadmiarowe krzyżyki. O głosach nieważnych w wyborach do sejmików województw [w:] J. Załuska (red.), Co się stało 16 listopada? Wybory samorzadowe 2014, Fundacja im. Stefana Batorego, Warszawa.

Gendźwiłł A. (2015b), Skąd się biorą głosy nieważne w wyborach do sejmików województw?, „Studia Socjologiczne”, 4. 
Gendźwiłł A., Cześnik M., Flis J., Haman J., Materska-Sosnowska A., Michalak B., Pietrzyk P., Zbieranek J. (2016), Nieważne głosy, ważny problem. Wyniki badania kart do głosowania z wyborów do sejmików województw 2014, Fundacja im. Stefana Batorego, Warszawa.

Michalak B. (2016a), Terytorialny rozkład głosów nieważnych podczas wyborów proporcjonalnych w Polsce a wybory samorzadowe 2014, „Studia Wyborcze”, 21.

Michalak B. (2016b), Wnioski i postulaty (nie tylko) de lege ferenda w obliczu kryzysu w wyborach samorzadowych 2014 r., „Białostockie Studia Prawnicze”, 20A.

Kancelaria Sejmu (2015), Opinia do ustawy o zmianie ustawy - Kodeks wyborczy, druk nr 901, Warszawa, 25 maja 2015 roku.

Protokół nr K1 z badania kart do głosowania z Obwodowej Komisji Wyborczej nr 2 w Brygidowie, Brygidów 1, 29-105 Krasocin, przeprowadzonego w Archiwum Państwowym w Kielcach, Kielce, 5 października 2015 roku.

Protokół nr K10 z badania kart do głosowania z Obwodowej Komisji Wyborczej nr 2 Dom Ludowy w Woli Rafałowskiej, Wola Rafałowska 137, 36-017 Błędowa Tyczyńska, przeprowadzonego w Archiwum Państwowym w Kielcach, Kielce, 6 października 2015 roku.

Protokół nr K11 z badania kart do głosowania z Obwodowej Komisji Wyborczej nr 3 w Korniaktowie Północnym, Korniaktów Północny 33a, 37-114 Białobrzegi, przeprowadzonego w Archiwum Państwowym w Kielcach, Kielce, 6 października 2015 roku.

Protokół nr K12 z badania kart do głosowania z Obwodowej Komisji Wyborczej nr 7 w Zespole Szkoły Podstawowej i Gimnazjum, Grabno 285, 32-830 Wojnicz, przeprowadzonego w Archiwum Państwowym w Kielcach, Kielce, 6 października 2015 roku.

Protokół nr K13 z badania kart do głosowania z Obwodowej Komisji Wyborczej nr 3, Szerzyny, Czermna 11, 38-245 Czermna, przeprowadzonego w Archiwum Państwowym w Kielcach, Kielce, 7 października 2015 roku.

Protokół nr K14 z badania kart do głosowania z Obwodowej Komisji Wyborczej nr 58 w Zespole Szkół Technicznych im. Ignacego Mościckiego w Tarnowie, ul. Kwiatkowskiego 17, 33-100 Tarnów, przeprowadzonego w Archiwum Państwowym w Kielcach, Kielce, 7 października 2015 roku.

Protokół nr K15 z badania kart do głosowania z Obwodowej Komisji Wyborczej nr 43 w Tarnowie, ul. Mickiewicza 16, 33-100 Tarnów, przeprowadzonego w Archiwum Państwowym w Kielcach, Kielce, 7 października 2015 roku.

Protokół nr K16 z badania kart do głosowania z Obwodowej Komisji Wyborczej nr 8 w Budynku Komunalnym, Piaski-Drużków 1, 32-860 Czchów, przeprowadzonego w Archiwum Państwowym w Kielcach, Kielce, 7 października 2015 roku.

Protokół nr K17 z badania kart do głosowania z Obwodowej Komisji Wyborczej nr 7 w Wolbromiu, Kąpiele Wielkie 75a, 32-340 Wolbrom, przeprowadzonego w Archiwum Państwowym w Kielcach, Kielce, 7 października 2015 roku.

Protokół nr K18 z badania kart do głosowania z Obwodowej Komisji Wyborczej nr 18 w Wiejskim Domu Kultury, Myślachowice, ul. Trzebińska 1, 32-543 Trzebinia, przeprowadzonego w Archiwum Państwowym w Kielcach, Kielce, 7 października 2015 roku.

Protokół nr K19 z badania kart do głosowania z Obwodowej Komisji Wyborczej nr 398, os. Złotej Jesieni 16, 31-828 Kraków, przeprowadzonego w Archiwum Państwowym w Kielcach, Kielce, 8 października 2015 roku. 
Protokół nr K2 z badania kart do głosowania z Obwodowej Komisji Wyborczej nr 1 w Łagowie, ul. Zapłotnia 1, 26-025 Łagów, przeprowadzonego w Archiwum Państwowym w Kielcach, Kielce, 5 października 2015 roku.

Protokół nr K20 z badania kart do głosowania z Obwodowej Komisji Wyborczej nr 1 w Kiczorach 60, 34-483 Lipnica Wielka, przeprowadzonego w Archiwum Państwowym w Kielcach, Kielce, 8 października 2015 roku.

Protokół nr K21 z badania kart do głosowania z Obwodowej Komisji Wyborczej nr 11 w Szkole Podstawowej w Sitnicy, Sitnica, 38-323 Rożnowice, przeprowadzonego w Archiwum Państwowym w Kielcach, Kielce, 8 października 2015 roku.

Protokół nr K22 z badania kart do głosowania z Obwodowej Komisji Wyborczej nr 7 w Łuszczaczu 1 w Szkole Podstawowej, 22-672 Susiec, przeprowadzonego w Archiwum Państwowym w Kielcach, Kielce, 8 października 2015 roku.

Protokół nr K23 z badania kart do głosowania z Obwodowej Komisji Wyborczej nr 2 w Szkole Podstawowej w Korytkowie Dużym 118, 23-400 Biłgoraj, przeprowadzonego w Archiwum Państwowym w Kielcach, Kielce, 8 października 2015 roku.

Protokół nr K 24 z badania kart do głosowania z Obwodowej Komisji Wyborczej nr 3 w Przedszkolu nr 1 w Tomaszowie Lubelskim, ul. Chocimska 19, 22-600 Tomaszów Lubelski, przeprowadzonego w Archiwum Państwowym w Kielcach, Kielce, 8 października 2015 roku.

Protokół nr K25 z badania kart do głosowania z Obwodowej Komisji Wyborczej nr 16 w Ośrodku Rehabilitacyjno-Edukacyjno-Wychowawczym w Jarosławiu, os. im. Wincentego Witosa 18, 37-500 Jarosław, przeprowadzonego w Archiwum Państwowym w Kielcach, Kielce, 8 października 2015 roku.

Protokół nr K26 z badania kart do głosowania z Obwodowej Komisji Wyborczej nr 3 w Szkole Podstawowej, Snopków 50, 21-002 Jastków, przeprowadzonego w Archiwum Państwowym w Kielcach, Kielce, 9 października 2015 roku.

Protokół nr K27 z rozpoznania materiałów z Obwodowej Komisji Wyborczej nr 3 w Świetlicy OSP, Stryj 27A, 08-550 Kłoczew, przeprowadzonego w Archiwum Państwowym w Kielcach, Kielce, 9 października 2015 roku.

Protokół nr K28 z badania kart do głosowania z Obwodowej Komisji Wyborczej nr 3 z Remizy OSP, Łopiennik 127, 24-224 Borzechów, przeprowadzonego w Archiwum Państwowym w Kielcach, Kielce, 9 października 2015 roku.

Protokół nr K29 z badania kart do głosowania z Obwodowej Komisji Wyborczej nr 13 z Przedszkola nr 8, Krasnystaw, ul. Tokarzewskiego 49, 22-300 Krasnystaw, przeprowadzonego w Archiwum Państwowym w Kielcach, Kielce, 9 października 2015 roku.

Protokół nr K3 z badania kart do głosowania z Obwodowej Komisji Wyborczej nr 26 w Ostrowcu Świętokrzyskim, ul. Akademicka 12, 27-400 Ostrowiec Świętokrzyski, przeprowadzonego w Archiwum Państwowym w Kielcach, Kielce, 5 października 2015 roku.

Protokół nr K4 z badania kart do głosowania z Obwodowej Komisji Wyborczej nr 7 w Suchedniowej, ul. Kielecka 11, 26-130 Suchedniów, przeprowadzonego w Archiwum Państwowym w Kielcach, Kielce, 5 października 2015 roku.

Protokół nr K5 z badania kart do głosowania z Obwodowej Komisji Wyborczej nr 68 w Kielcach, przeprowadzonego w Archiwum Państwowym w Kielcach, Kielce, 5 października 2015 roku. 
Protokół nr K6 z badania kart do głosowania z Obwodowej Komisji Wyborczej nr 15 w Nieświniu, ul. Szkolna 5, 26-200 Końskie, przeprowadzonego w Archiwum Państwowym w Kielcach, Kielce, 5 października 2015 roku.

Protokół nr K7 z badania kart do głosowania z Obwodowej Komisji Wyborczej nr 4 w Hyżnem 791, 36-024 Hyżne, przeprowadzonego w Archiwum Państwowym w Kielcach, Kielce, 6 października 2015 roku.

Protokół nr K8 z badania kart do głosowania z Obwodowej Komisji Wyborczej nr 17 w Szkodnej 121, 39-126 Zagorzyce, przeprowadzonego w Archiwum Państwowym w Kielcach, Kielce, 6 października 2015 roku.

Protokół nr K9 z badania kart do głosowania z Obwodowej Komisji Wyborczej nr 9 w Maleniskach 75, 73-307 Brzóza Królewska, przeprowadzonego w Archiwum Państwowym w Kielcach, Kielce, 6 października 2015 roku.

Ptak A. (2012), Głosy nieważne w elekcjach samorządowych, „Przegląd Politologiczny”, 4.

Sieklucki D. (2015), Praktyczne konsekwencje zmian samorządowego systemu wyborczego w Kodeksie wyborczym - uwagi i refleksje na tle wyborów z 2014 roku, ,Polityka i Społeczeństwo", 3.

Skotnicki K. (2011), Przebieg prac nad kodeksem wyborczym [w:] K. Skotnicki (red.), Kodeks wyborczy. Wstepna ocena, Wydawnictwo Sejmowe, Warszawa.

Stelmach A. (2010), Zmiany prawa wyborczego w Polsce a legitymizacja władzy [w:] A. Stelmach (red.), Prawo wyborcze $i$ wybory. Doświadczenia dwudziestu lat procesów demokratyzacyjnych $w$ Polsce, Wydział Nauk Politycznych i Dziennikarstwa UAM, Poznań.

Śleszyński P. (2015), Hipotezy głosów nieważnych w wyborach powszechnych po 1989 r., „Przestrzeń społeczna”, 2.

\section{Akty prawne}

Konstytucja Rzeczypospolitej Polskiej z dnia 2 kwietnia 1997 roku, Dz.U. 1997, nr 78, poz. 483 ze zm.

Uchwała Państwowej Komisji Wyborczej z dnia 29 września 2014 roku w sprawie wytycznych dla obwodowych komisji wyborczych dotyczących zadań i trybu przygotowania oraz przeprowadzenia głosowania w wyborach organów jednostek samorządu terytorialnego, zarządzonych na dzień 16 listopada 2014 roku, M.P. 2014, poz. 934.

Ustawa z dnia 12 kwietnia 2001 roku Ordynacja wyborcza do Sejmu Rzeczypospolitej Polskiej i do Senatu Rzeczypospolitej Polskiej, Dz.U. 2007, nr 190, poz. 1360 teskt jedn. ze zm.

Ustawa z dnia 16 lipca 1998 roku Ordynacja wyborcza do rad gmin, rad powiatów i sejmików województw, Dz.U. 2010, nr 176, poz. 1190 ze zm.

Ustawa z dnia 20 czerwca 2002 roku o bezpośrednim wyborze wójta, burmistrza i prezydenta miasta, Dz.U. 2010, nr 176, poz. 1191.

Ustawa z dnia 23 stycznia 2004 roku Ordynacja wyborcza do Parlamentu Europejskiego, Dz.U. 2004, nr 25, poz. 219 ze zm.

Ustawa z dnia 27 września 1990 roku o wyborze Prezydenta Rzeczypospolitej Polskiej, Dz.U. 2010, nr 72, poz. 467 ze zm.

Ustawa z dnia 5 stycznia 2011 roku - Kodeks wyborczy, Dz.U. 2019, poz. 684 tekst jedn. ze zm. 